\title{
Screening of Antimicrobial and Antioxidant Activity of Acetone Extracts of Heritiera fomes Whole Plant against Pathogens
}

\author{
Chepuri Kalyani, Chidepudi Devi Sri Lalitha Naga Tulasi, Swathi Minumula Sudarshan, Adelli Geetha, Mangamoori Lakshmi Narasu, \\ Lavudi Saida* \\ Centre for Biotechnology, Institute of Science and Technology, JNTUH, Kukatpally, Hyderabad, Telangana, INDIA.
}

\begin{abstract}
Background: Phytochemicals are well known to have many important pharmaceutical properties. Heritiera fomes grows in low saline environments. The present study was initiated to explore the biologically beneficial properties of $H$. fomes. Methods: The crude extracts of $H$. fomes were extracted in acetone by orbital shaker and concentrated using rota evaporator. Total flavonoid content and Total phenolic content were estimated spectrophotometrically and the in-vitro antioxidant capacity was estimated by DPPH (2,2-diphenyl-1-picrylhydrazyl), Ferric Reducing Antioxidant Power (FRAP) and Hydrogen peroxide $\left(\mathrm{H}_{2} \mathrm{O}_{2}\right)$ Scavenging Assays. Anti-microbial activity was determined by Disc diffusion method. Results: Phytochemical screening of acetone extract of $H$. fomes showed the presence of major classes of phytochemicals like alkaloids, glycosides, flavonoids, saponins, carbohydrates, phenols and sterols in considerable quantity. The total amount of phenolic and flavonoid content was found to be $75.3 \mathrm{mg} \mathrm{GAE} / \mathrm{g}$ dry weight and $61.3 \mathrm{mg} \mathrm{OE} / \mathrm{g}$ dry weight respectively. Antioxidant activity of plant extract determined by using different assays like $\mathrm{H}_{2} \mathrm{O}_{2}$ radical scavenging, DPPH and FRAP. A positive correlation between all the pairs of antioxidant assays was observed. Further, antimicrobial
\end{abstract}

activity against various pathogens was evaluated by disc diffusion method where the zone of inhibitions were found to be in range from $5 \pm 0.35$ to $12 \pm 0.50 \mathrm{~mm}$. Conclusion: The study concludes that the plant Heritiera fomes has its effect in scavenging free radicals and has a potential to be a power antioxidant. Several in-vitro studies possess significant antioxidant, antimicrobial activities. The present study plays an important tool for new drug discovery.

Key words: Heritiera fomes, Total phenolic content, Total Flavonoid content, $\mathrm{H}_{2} \mathrm{O}_{2}$ radical scavenging assay, DPPH assay, FRAP assay, Antioxidant activity, Antimicrobial activity, Disc diffusion method.

\section{Correspondence}

Dr. Lavudi Saida

Assistant Professor \& Addl. Controller of Examinations, Centre for Biotechnology, Institute of Science \& Technology, Jawaharlal Nehru Technological University Kukatpally, Hyderabad-500085, Telangana, INDIA.

Phone no: +919618528040

Email: yrvlm.chidepudi@gmail.com

DOI: 10.5330/ijpi.2020.4.98

\section{INTRODUCTION}

Phytochemicals are also non-nutritive chemicals that are produced from plants. Plants have wide variety of secondary metabolites such as tannins, alkaloids, phenolic compounds, flavonoids etc. that been found in-vitro to show the antimicrobial properties. ${ }^{1}$ In therapeutics, the use of crude extracts from plants and their phytochemicals, known to have antimicrobial properties, are an excellent importance. Heritiera. fomes belongs to the family: Malvacea which grows abundantly in the Sundarbans. It is commonly known as "Sundari". H. fomes is a mangrove tree which is widely spread over in the sundarbans mangrove forest, Bangladesh. By nature it is a mangrove species. It can grow up to height of $25 \mathrm{~m}$ and its trunk can be about $50 \mathrm{~cm}$ in diameter. This mangrove forest is named after the plant $H$. fomes and it is grown densely in this mangrove forest. It preferably grows in low saline environments. The present study was initiated to explore the biologically beneficial properties of $H$. fomes.

\section{MATERIALS AND METHODS}

\section{Materials}

Microbial culture: The bacterial strains were Eschericia coli (2412), Staphylococcus aureus (E40), Proteus vulgaris (2266), Klebsiella aerogenes (U98), Bacillus cereus (2128), Staphylococcus epidermidis (2120) were collected from MTCC Mumbai. The culture was prepared by using Nutrient Broth. Nutrient broth was added with $50 \mu$ of culture in sterile test tubes and kept for incubation for $24 \mathrm{hr}$.

\section{Plant collection and Extraction}

Plant material was collected from Sri Venkateshwara University, Tirupati. To extract the crude compounds, the plant material was diluted with acetone $(1: 10 \mathrm{w} / \mathrm{v})$ and kept at room temperature for $24 \mathrm{hr}$ without disturbing. After $24 \mathrm{hr}$, it was kept in orbital shaker for the next $48 \mathrm{hr}$. The diluted plant sample was filtered by using Whatman No.1 filter paper to get crude extract. Now the extract was air dried and concentrated at room temperature. The dried concentrated crude extract was weighed and stored at room temperature for further purposes.

\section{Phytochemical Characterization}

The preliminary screening of phytochemicals like alkaloids, glycosides, flavonoids, saponins, sterols, tannins, aminoacids, terpenoids, quinones, diterpenes, resins, phenols was done by taking crude extract a stock of $1 \mathrm{mg} / \mathrm{ml}$ and by following standard procedures. ${ }^{2}$

\section{Antioxidant Activity \\ DPPH (2, 2-diphenyl-1-picrylhydrazyl) method}

DPPH assay of $H$. fomes extract was evaluated by using the standard method $^{3}$ with very slight modifications. Ascorbic acid of different concentrations $(2.5-15 \mu \mathrm{g} / \mathrm{ml})$ was used as reference standard. For determining the DPPH scavenging ability, $1 \mathrm{ml}$ of plant extract of different concentrations $(25-200 \mu \mathrm{g} / \mathrm{ml})$ was treated with $1 \mathrm{ml}$ of $0.2 \mathrm{mM}$ $\mathrm{DPPH}$ solution in ethanol. The total reaction mixture was incubated in 
dark at room temperature for $30 \mathrm{~min}$. After incubation, the absorbance was measured at $517 \mathrm{~nm}$. The ability of plant extract to scavenge the DPPH radical was calculated as the percentage of inhibition using the following formula

DPPH Scavenging activity $(\%)=\frac{\left[\mathrm{A}_{\text {control }}{ }^{-}\left(\mathrm{A}_{\text {sample }}-\mathrm{A}_{\text {sampleblank }}\right)\right]}{\mathrm{A}_{\text {control }}}{ }^{\star} 100$

Where,

$\mathrm{A}_{\text {control }}=1 \mathrm{ml}$ of DPPH solution $+1 \mathrm{ml}$ of ethanol.

$\mathrm{A}_{\text {sample blank }}=1 \mathrm{ml}$ of plant extract $+1 \mathrm{ml}$ of methanol.

$\mathrm{A}_{\text {sample }}=$ absorbance of sample.

Inhibitory concentration $50 \%\left(\mathrm{IC}_{50}\right.$ ) value was obtained from the linear regression line. The antioxidant activity was determined by $\mathrm{IC}_{50}$ value.

\section{FRAP (Ferric Reducing Antioxidant Power Assay) method}

Ferric reducing ability of $H$. fomes extract was measured by using standard protocol. ${ }^{4}$ For this, the FRAP reagent was prepared as 10:1:1 $\mathrm{v} / \mathrm{v} / \mathrm{v}$ of $300 \mathrm{Mm}$ Sodium acetate buffer where $\mathrm{pH}$ is adjusted to 3.6, $10 \mathrm{mM}$ TPTZ (2,4,6-Tri-(2-pyridyl)-5-triazine) in $40 \mathrm{Mm} \mathrm{HCl}$ and $20 \mathrm{Mm}$ Ferric chloride hexahydrate $\left(\mathrm{FeCl}_{3} \cdot 6 \mathrm{H}_{2} \mathrm{O}\right)$. By using ferrous sulphate $\left(\mathrm{FeSO}_{4}\right)$ of different concentrations $(0.2-1.0 \mathrm{mM})$ standard, a calibration curve was plotted. As reference standard, Ascorbic acid $(100-500 \mu \mathrm{g} / \mathrm{ml})$ was used. To determine the ferric ion reducing ability, $1 \mathrm{ml}$ of plant extract of different concentrations $(200-1000 \mu \mathrm{g} / \mathrm{ml})$ were treated with $3 \mathrm{ml}$ of freshly prepared FRAP reagent and $1 \mathrm{ml}$ of distilled water. All these experiments were done in triplicates. The total reaction mixture was kept for incubation at $37^{\circ} \mathrm{C}$ for $30 \mathrm{~min}$. After incubation, the absorbance was measured at $593 \mathrm{~nm}$ and is expressed as $\mathrm{mM} \mathrm{FeSO}_{4}$ equivalent/gm of plant extract.

\section{Hydrogen peroxide scavenging assay $\left(\mathrm{H}_{2} \mathrm{O}_{2}\right)$}

$\mathrm{H}_{2} \mathrm{O}_{2}$ Scavenging assay of acetone extract of $H$. fomes was evaluated by using the method ${ }^{5}$ with slight modifications. For this, $20 \mathrm{mM}$ of $\mathrm{H}_{2} \mathrm{O}_{2}$ was prepared in $50 \mathrm{mM}$ Phosphate buffer and $\mathrm{pH}$ was adjusted to 7.4. In this assay, ascorbic acid of different concentrations $(10-50 \mu \mathrm{g} / \mathrm{ml})$ were used as reference standard. For determining the scavenging ability, $1 \mathrm{ml}$ of plant extract of different concentrations $(10-200 \mu \mathrm{g} / \mathrm{ml})$ was dissolved in phosphate buffer that was treated with $2 \mathrm{ml}$ of $20 \mathrm{mM} \mathrm{H}_{2} \mathrm{O}_{2}$ solution. The total reaction mixture was kept for incubation at room temperature for 10 min in dark. After incubation, the absorbance was measured at 230nm using UV-Vis-Spectrophotometer. The scavenging ability of the plant extract and the standard to scavenge $\mathrm{H}_{2} \mathrm{O}_{2}$ molecules was calculated as percentage of inhibition using the formula-

$\mathrm{H}_{2} \mathrm{O}_{2}$ Scavenging ability $(\%)=\frac{\left[\mathrm{A}_{\text {control }}-\left(\mathrm{A}_{\text {sample }}-\mathrm{A}_{\text {sample blank }}\right)\right]}{\mathrm{A}_{\text {control }}} * 100$

Where,

$\mathrm{A}_{\text {control }}-2 \mathrm{ml}$ of $\mathrm{H}_{2} \mathrm{O}_{2}$ solution $+1 \mathrm{ml}$ of phosphate buffer.

$\mathrm{A}_{\text {sample }}$ - absorbance of sample.

$\mathrm{A}_{\text {sampleblank }}-1 \mathrm{ml}$ of plant extract $+2 \mathrm{ml}$ of phosphate buffer.

Phosphate buffer is used as blank solution.

The inhibitory concentration $50 \%$ of $\mathrm{H}_{2} \mathrm{O}_{2}$ molecules is obtained from linear regression line. The antioxidant activity of plant extract is evaluated from $\mathrm{IC}_{50}$ value.

\section{Total flavonoid content}

Total flavonoid content of acetone extract of $H$. fomes was evaluated by using Aluminum chloride colorimetric method ${ }^{6}$ with slight modifications. Quercitin dihydrate is used as reference standard and a calibration curve was plotted by using different concentrations $(20-100 \mu \mathrm{g} / \mathrm{ml})$. For determining total flavonoid content, $500 \mu \mathrm{l}$ plant extract of different concentrations $(200-1000 \mu \mathrm{g} / \mathrm{ml})$ or Quercitin was mixed with $1.5 \mathrm{ml}$ methanol, $0.1 \mathrm{ml} \mathrm{AlCl}_{3}, 0.1 \mathrm{ml}$ potassium acetate and $2.8 \mathrm{ml}$ of distilled water. The total reaction mixture was incubated at room temperature in dark for $30 \mathrm{~min}$. After incubation, absorbance was measured at $415 \mathrm{~nm}$ by UV-Vis-Spectrophotometer. A blank was prepared by taking all reagents except aluminum chloride. Total flavonoid content was expressed as mg Quercitin equivalent (QE)/gm dry weight.

\section{Total phenolic content}

The total phenolic content of acetone extract of $H$. fomes was determined by using Folin-Ciocalteu method. ${ }^{7}$ A calibration curve of gallic acid of different concentrations $(20-100 \mu \mathrm{g} / \mathrm{ml})$ was plotted as standard. For this, $200 \mu \mathrm{l}$ plant extract of different concentrations $(200-1000 \mu \mathrm{g} /$ $\mathrm{ml}$ ) was mixed with $2.8 \mathrm{ml}$ of distilled water and $0.25 \mathrm{ml}$ of FolinCiocalteu reagent $(1: 10 \mathrm{v} / \mathrm{v})$. After $5 \mathrm{~min}$ of duration, $0.75 \mathrm{ml}$ of Sodium carbonate $(7.5 \% \mathrm{w} / \mathrm{v})$ was added. The total reaction mixture was kept for incubation at room temperature in dark for $30 \mathrm{~min}$. After incubation, the absorbance of standard and the sample was measured at $765 \mathrm{~nm}$ by UV-Vis-Spectrophotometer. Distilled water was used as blank. Total phenolic content was expressed as mg gallic acid equivalents (GAE)/gm dry weight.

\section{Antimicrobial Activity \\ Disc Diffusion Method}

The most widely used method for determining the anti-microbial activity is Disc diffusion method. This method is mainly used to test the effectiveness of antibiotics on organisms. Antibiotic discs were prepared by using Whatman No.1 filter paper, of size-4mm. Gram positive organisms and Gram negative organisms used in the present study were Staphylococcus epidermidis, Bacillus cereus, Staphylococcus aureus, E.coli, Klebsiella aerogens, Proteus vulgaris respectively.

On the surface of the agar plates, bacterial strains were inoculated and evenly spread with the help of glass rod. Discs of plant extract of concentration $8 \mathrm{mg} / \mathrm{ml}$ and $16 \mathrm{mg} / \mathrm{ml}$ were placed on the surface of the agar plates. These plates were closed tightly with the help of parafilm. All this work should be done in laminar air flow chamber. The anti-microbial compound starts diffusing into the surrounding agar. All these plates were kept in incubator for $24 \mathrm{hr}$ at $37^{\circ} \mathrm{C}$. Now, simultaneously the growth of the bacteria and the diffusion of the anti-microbial compound begins. After incubation, zone of inhibition were formed and are measured for all the bacterial strains. Simultaneously, amikacin antibiotic of different concentrations is used for comparison between plant extract of different concentrations

\section{Minimum Inhibitory Concentration (MIC) and Minimum Bactericidal Concentration (MBC)}

In this method, seven test tubes were taken out of which one tube is kept as blank. In all the test tubes, an equal volume $(5 \mathrm{ml})$ of Nutrient Broth was taken in all the test tubes. To this $500 \mathrm{mg}$ of plant extract was taken in the first tube. From this tube, $1 \mathrm{ml}$ of broth was taken and a serial dilution was done in all the tubes and $1 \mathrm{ml}$ of broth is discarded out from the last tube. Now, to each tube add $50 \mu \mathrm{l}$ of culture was added in all the test tubes and these tubes were incubated at $37^{\circ} \mathrm{C}$ for $24 \mathrm{hr}$. After incubation, the results were validated and the MIC and $\mathrm{MBC}$ concentrations were determined. ${ }^{8,9}$ 


\section{RESULTS}

\section{Phytochemical screening}

The quantitative phytochemicals analysis of this species exhibited the presence of alkaloids, glycosides, flavonoids, saponins, carbohydrates, phenols and sterols in considerable quantity (Table 1).

\section{Total phenolic content and total flavonoid content}

Total phenolic content and flavonoid content of $H$. fomes was determined by linear regression equation of gallic acid $\left(\mathrm{y}=0.0013 \mathrm{x}+0.0131, r^{2}=0.9956\right)$ and quercitin $\left(\mathrm{y}=0.0019 \mathrm{x}-0.0136, r^{2}=0.9904\right)$ respectively. Total phenolic content and total flavonoid content was calculated and expressed as mg GAE/g dry extract and mg QE/g dry extract.

The total amount of phenolic content present in the plant extract was 75.3 GAE/g dry weight and the total amount of flavonoid content present in the plant extract was $61.3 \mathrm{QE} / \mathrm{g}$ dry weight (Table 2).

\section{Antioxidant activity DPPH Scavenging Assay}

$\mathrm{DPPH}$ is most widely used antioxidant activity. It is rapid, economic and simple activity. It contains unpaired electrons and shows maximum absorption at $517 \mathrm{~nm}$. It reduces the unpaired electron on DPPH by donating an hydrogen atom. ${ }^{10}$ Therefore, a decrease in the intensity of deep violet colour is observed, which is proportional to antioxidant activity.

As the transfer of hydrogen atom to DPPH radical is slow, it is considered as electron transfer (ET) based assay even though there is a hydrogen atom transfer. The acetone extract of $H$. fomes has shown scavenging activity against DPPH with $\mathrm{IC}_{50}$ of $182.43 \mu \mathrm{g} / \mathrm{ml}$ (Table 3).

\section{$\mathrm{H}_{2} \mathrm{O}_{2}$ Scvenging Assay}

$\mathrm{H}_{2} \mathrm{O}_{2}$ do not contain unpaired electrons and is non-free radical. $\mathrm{H}_{2} \mathrm{O}_{2}$ is a strong oxidizing agent and undergoes reduction by accepting hydrogen from antioxidant. During this process, $\mathrm{H}_{2} \mathrm{O}_{2}$ gets neutralized to $\mathrm{H}_{2} \mathrm{O}$. It

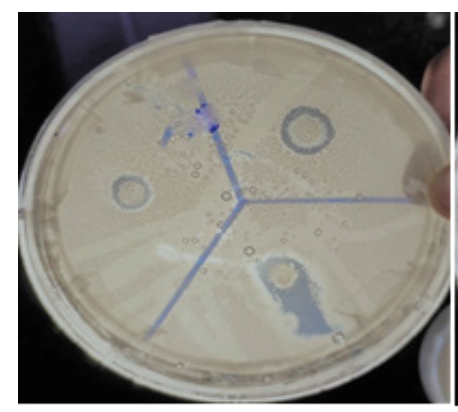

(A) Staphylococcus aureus

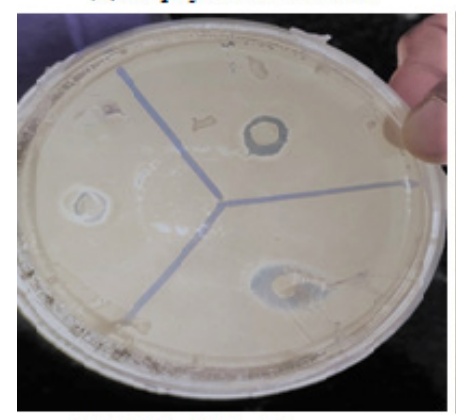

(C) Escherichia coli

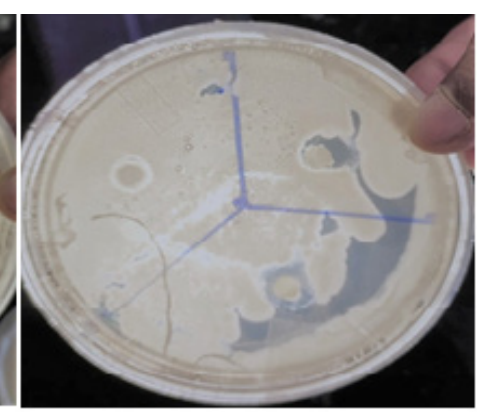

(B) Klebsiella aerogens

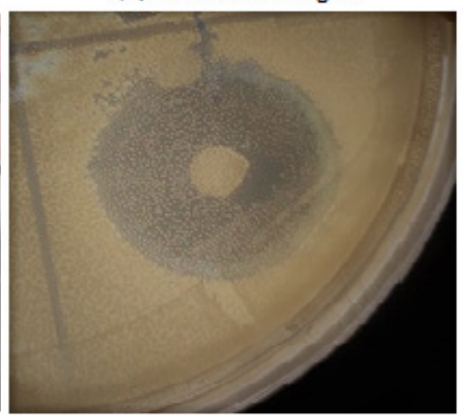

(D) Proteus vulgaris
Figure 1: Antimicrobial activity of $H$. fomes of acetone plant extract. shows maximum absorption at $230 \mathrm{~nm}$. The decrease in the absorbance of $\mathrm{H}_{2} \mathrm{O}_{2}$ is proportional to the activity of antioxidant. The present study has abundant phenolic compounds which contribute to antioxidant activity with $\mathrm{IC}_{50} 71.991 \mu \mathrm{g} / \mathrm{ml}$ (Table 3 ).

Each value is the average of three analyses \pm standard deviation. Means sharing the same letter are significant at $P<0.01$.

\section{FRAP (Ferric reducing antioxidant power) Assay}

FRAP assay is most widely used antioxidant activity. In acidic medium, the ferric 2,4,6-tripyridyl-s-triazine complex [Fe(III)- (TPTZ) $\left.]_{2}\right]^{+3}$ was reduced to intense blue coloured ferrous complex [Fe(II)-(TPTZ) $\left.)_{2}\right)^{2+}$. Maximum absorbance was measured at $593 \mathrm{~nm}$ wavelength and expressed as $\mu \mathrm{M}$ ferrous ion $\left(\mathrm{Fe}^{2}\right)$ equivalents. There is a clear correlation between the plant extract activity and standard, with increasing concentrations the activity increased showing the potency of the plant extract (Table 4).

\section{Antimicrobial activity of $H$. fomes against pathogens}

The Table 5 and Figures 1,2,3 depicts the antimicrobial activity of extract against the gram positive and gram negative bacteria. The acetone extract of $H$. fomes, showed maximum zone of inhibition with the diameter of 12 $\pm 0.50 \mathrm{~mm}$ against the gram negative bacterium-Proteus vulgaris.

The acetone extract was compared with an antibiotic drug, Amikacin which showed its maximum zone of inhibition against the gram negative bacteria- Klebsiella aerogens with the diameter of $26 \mathrm{~mm}$.

\section{Minimum Inhibitory concentration (MIC) and Minimum Bactericidal Concentration (MBC)}

After the completion of the incubation period, the well were checked and based on the turbidity of the plates the MIC and MBC values were evaluated and plotted in the below Table 6 .

Acetone extract had shown potent result inhibiting the growth of different pathogens like Staphylococcus aureus, Escherichia coli, Staphylococcus epidermidis and Bacillus cereus.

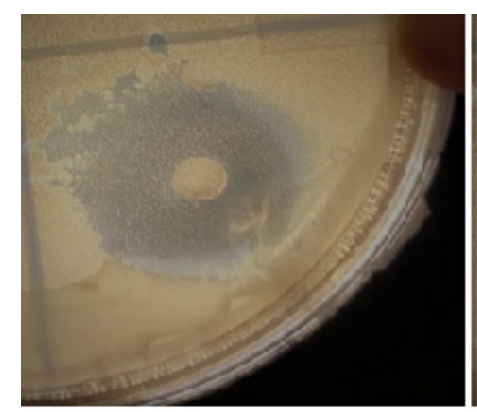

(A) Escherichia coli

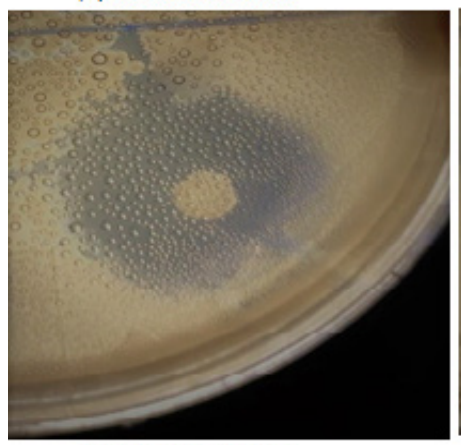

(C) Proteus vulgaris

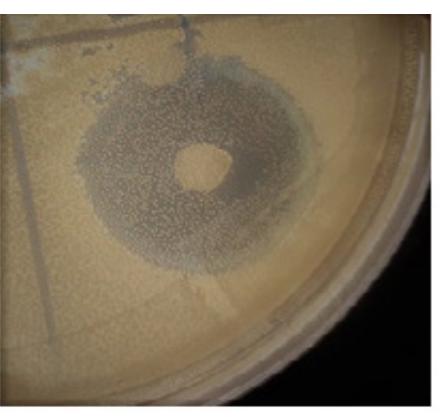

(B)Klebsiella aerogens

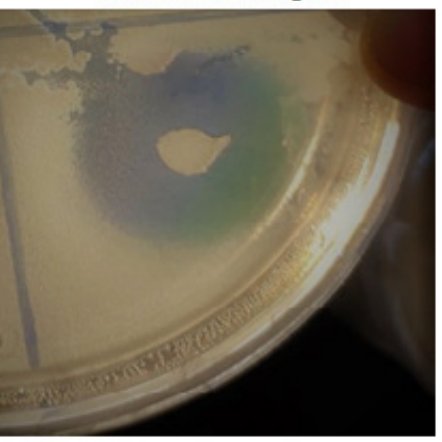

(D) Staphylococcus aureus
Figure 2: Antimicrobial activity of an Antibiotc (Amikacin). 


\section{DISCUSSION}

Heritiera fomes is a very predominant mangrove species. As per literature available on this species regarding its biological activities, it has enoromous potential. $H$. fomes contains $0.09 \%$ chlorophyll b, $0.25 \%$ chlorophyll A, $0.11 \%$ carotenoids, $21.12 \%$ tannins, $39.45 \%$ polyphenols. ${ }^{11}$ The presence of reducing sugars, alkaloids, saponins, glycosides, steroids, tannins, flavonoids and gums was demonstrated by phytochemical screening of leaf extract. ${ }^{12}$ Leaf contains $29.22 \%$ protein. ${ }^{13}$ The bark of $H$. fomes possess high amount of proanthocyanidins ${ }^{14}$ and $7-36 \%$ tannin. ${ }^{15}$ The bark of stem contains high content of procyanidins, which are found to be trimeric, pentameric and hexameric.

Table 1: Results of phytochemical constituents.

\begin{tabular}{ccc}
\hline Test performed & $\begin{array}{c}\text { Phytochemical } \\
\text { constituent }\end{array}$ & $\begin{array}{c}\text { Acetone } \\
\text { extract }\end{array}$ \\
\hline Wagner's test & Alkaloids & + \\
Keller-kellani's test & Glycosides & + \\
Alkaline reagent test & Flavonoids & + \\
Foam test & Saponins & + \\
Molisch's test & Carbohydrates & + \\
Ferric chloride test & Phenols & + \\
Liebermann-Burchard test & Sterols & + \\
Braymers test & Tannins & - \\
Ninhydrin test & Amino acids and Proteins & - \\
Salkowki's test & Terpenoids & - \\
Concentrated.HCL test & Quinones & - \\
Copper acetate test & Diterpenes & - \\
Turbidity test & Resins & \\
\hline
\end{tabular}

Table 2: The total phenolic and flavonoid content of $\boldsymbol{H}$. fomes.

\begin{tabular}{ccc}
\hline S. No & Assay & Content \\
\hline 1 & Total Phenolic content & $75.3 \mathrm{GAE} / \mathrm{g}$ dry weight \\
2 & Total flavonoid content & $61.3 \mathrm{QE} / \mathrm{g}$ dry weight \\
\hline
\end{tabular}

Table 3: $\mathrm{IC}_{50}$ of $\boldsymbol{H}$. fomes. and reference standard.

\begin{tabular}{ccc}
\hline S. No & Antioxidant assay & $\mathrm{IC}_{50}$ values $(\mu \mathrm{g} / \mathrm{ml})$ \\
\hline 1 & DPPH Assay & $182.43^{\mathrm{a}}$ \\
2 & $\mathrm{H}_{2} \mathrm{O}_{2}$ Scvenging Assay & $71.991^{\mathrm{a}}$ \\
3 & Standard (Ascorbic acid) & $14.78^{\mathrm{a}}$ \\
\hline
\end{tabular}

Table 4: Ferric Reducing antioxidant power of $\boldsymbol{H}$. fomes.

\begin{tabular}{|c|c|c|c|c|c|}
\hline & \multicolumn{5}{|c|}{$\begin{array}{l}\text { Ascorbic acid (Standard) } \\
\text { Concentration }(\mu \mathrm{g} / \mathrm{ml})\end{array}$} \\
\hline & 100 & 200 & 300 & 400 & 500 \\
\hline \multirow[t]{3}{*}{$\begin{array}{l}\mathrm{mMFeSO}_{4} \text { per gram dry } \\
\text { weight of ascorbic acid }\end{array}$} & 0.169 & 0.598 & 0.953 & 1.111 & 1.364 \\
\hline & \multicolumn{5}{|c|}{ Acetone plant extract Concentration $(\mu \mathrm{g} / \mathrm{ml})$} \\
\hline & 200 & 400 & 600 & 800 & 1000 \\
\hline $\begin{array}{c}\mathrm{mMFeSO}_{4} \text { per gram dry } \\
\text { weight of extract }\end{array}$ & 0.099 & 0.485 & 0.766 & 0.780 & 0.800 \\
\hline
\end{tabular}

Leaf extract of Heritiera fomes was evaluated for both qualitative and quantitative antioxidant activity. Quantitative assay technique was carried out by DPPH assay (hydrogen donation assay) and qualitative assay was carried out by thin layer chromatographic technique followed by DPPH spray. Leaves extract exhibited noteworthy antioxidant activity with the $\mathrm{IC}_{50} 26.30 \mu \mathrm{g} / \mathrm{mL} .{ }^{12}$ Bark extracts of $H$. fomes exhibited potent antioxidant activity with $\mathrm{IC}_{50} 22 \mu \mathrm{g} / \mathrm{mL}^{2}$

Heritiera fomes leaf extract at dosage of $250 \mu \mathrm{g} / \mathrm{disc}$ and $500 \mu \mathrm{g} / \mathrm{disc}$ exhibited effective antimicrobial activity with the zones of inhibition against tested gram-negative and gram-positive pathogens at a range of 7.86 to $13.45 \mathrm{~mm}$ and 3.92 to $7.63 \mathrm{~mm}$ respectively. ${ }^{12}$ The bark extracts of $H$. fomes has shown promising antibacterial activities against $P$.

Table 5: Zone of inhibition evaluated with the acetone extract of $H$. fomes and Antibiotic (Amikacin).

\begin{tabular}{ccccc}
\hline S.No & Pathogens & Concentration & \multicolumn{2}{c}{ Zone of inhibition in mm } \\
\cline { 3 - 5 } & & $(\mu \mathrm{g} / \mathrm{ml})$ & $\begin{array}{c}\text { Acetone extract } \\
(\mu \mathrm{g} / \mathrm{ml})\end{array}$ & $\begin{array}{c}\text { Antibiotic } \\
(\text { Amikacin) } \\
(50 \mu \mathrm{g} / \mathrm{ml})\end{array}$ \\
\hline $1 \quad$ & & $5 \pm 0.35$ & $25 \pm 0.35$ \\
& Escherichia coli & 50 & $7 \pm 0.45$ & \\
& & 100 & $9 \pm 0.25$ & \\
2 & 150 & $5 \pm 0.50$ & $26 \pm 0.50$ \\
& Klebshella & 50 & $6 \pm 0.25$ & \\
& aeurogenes & 100 & $9 \pm 0.35$ & \\
& & 150 & $6 \pm 0.25$ & $24 \pm 0.25$ \\
& Proteus vulgaris & 50 & $8 \pm 0.35$ & \\
& & 100 & $12 \pm 0.50$ & \\
4 & & 150 & $6 \pm 0.15$ & $25 \pm 0.75$ \\
& Staphylococcus & 50 & $8 \pm 0.25$ & \\
& aureus & 100 & $10 \pm 0.25$ & \\
& & 150 & & \\
\hline
\end{tabular}

Table 6: Minimum Inhibitory Concentration (MIC) and Minimum Bactericidal Concentration (MBC) of plant extract against susceptible test organisms.

\begin{tabular}{ccc|}
\hline Pathogen & MIC $(\mathbf{m g} / \mathbf{m l})$ & MBC $(\mathbf{m g} / \mathbf{m l})$ \\
\hline Staphylococcus aureus & 0.8 & 4 \\
Escherichia coli & 0.8 & 4 \\
Staphylococcus epidermidis & 10 & 50 \\
Bacillus cereus & 4 & 20 \\
\hline
\end{tabular}

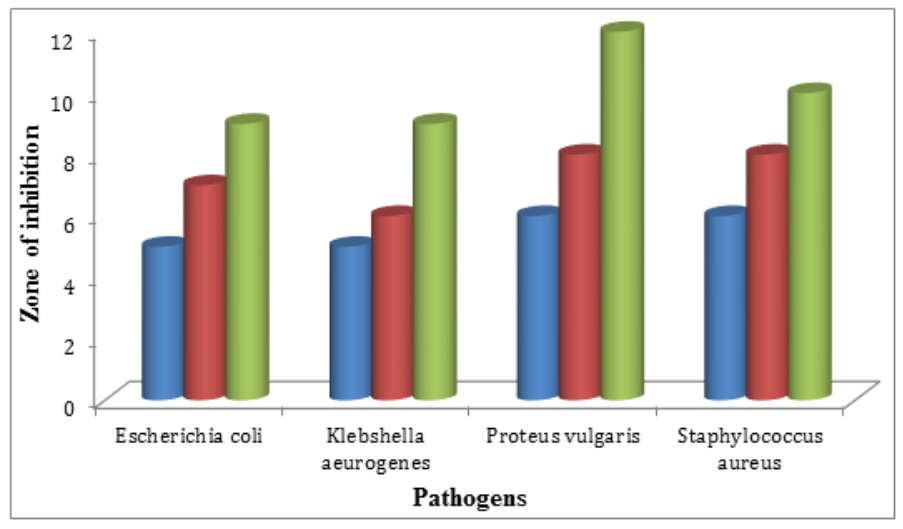

Figure 3: Zone of inhibition of various pathogens of $\mathrm{H}$. fomes acetone extract. Minimum Inhibitory concentration (MIC) and Minimum Bactericidal Concentration (MBC). 
aeruginosa, K. rhizophila, S. aureus and B. subtilis. ${ }^{2}$ In vitro antibacterial study between the pneumatophores of $H$. fomes and Xylocarpus moluccensis demonstrated comparable antibacterial profiles in the most cases with the zone of inhibitions $>10 \mathrm{~mm}$. Pneumatophores extract of H. fomes presented a potent antimicrobial activity against Enterobacter aerogenes with the diameter of zones between 19 and $21 \mathrm{~mm}$. The MIC (minimum inhibitory concentration) of $H$. fomes extract was evaluated by broth dilution method and showed significant minimum inhibitory concentration (MIC $=400$ and $500 \mu \mathrm{g} / \mathrm{mL}$ ) against Shigella boydii and Shigella sonnei, respectively. ${ }^{16}$

\section{CONCLUSION}

The study concludes that the plant Heritiera fomes has its effect in scavenging free radicals and has a potential to be a power antioxidant. Several in-vitro studies possess significant antioxidant, antimicrobial activities. The present study plays an important tool for new drug discovery.

\section{ACKNOWLEDGEMENT}

The authors acknowledge the Centre for Biotechnology, Institute of Science and Technology, Jawaharlal Nehru Technological University, Hyderabad for providing lab bench as well technical assistance to carryout the present research work

\section{CONFLICT OF INTEREST}

Authors declare no conflict of interest.

\section{REFERENCES}

1. Djeussi DE, Noumedem JA, Seukep JA, Fankam AG, Voukeng IK, Tankeo SB, et al. Antibacterial activities of selected edible plants extracts against multidrug resistant Gram-negative bacteria. BMC Complement MedTher. 2013;13(1):164.
2. Alex F. The Complete Illustrated Book of Herbs, the Reader's Digest Association. 2009.

3. Helle W, Huong CTD, Shaikh JU, Karl EM. Antioxidant and Antimicrobial Effects of the Mangrove Tree Heritiera fomes. Nat Prod Commun. 2009;4(3):371-6.

4. Benzie IF, Strain JJ. The ferric reducing ability of plasma (FRAP) as a measure of "antioxidant power: The FRAP assay. Anal Biochem. 1996;239(1):70-6.

5. Saumya SM, Basha PM. Antioxidant effect of Lagerstroemia speciosa Pers (Banaba) leaf extract in streptozotocin-induced diabetic mice. Indian J Exp Biol. 2011;49:125-31.

6. Kim DO, Jeong SW, Lee CY. Antioxidant capacity of phenolic phytochemicals from various cultivars of plums. Food Chem. 2003;81 (3):321-6.

7. Park YS, Jung ST, Kang SG, Heo BG, Arancibia-Avila P, Toledo F, et al. Antioxidants and proteins in ethylene-treated kiwifruits. Food Chem. 2008;107(2):6408.

8. Agatemor C. Antimicrobial activity of aqueous and ethanol extracts of nine Nigerian spices against four food borne bacteria. Elec J Env Agricult Food Chem. 2009;8(3):195-200.

9. Koochak H, Seyyednejad SM, Motamedi H. Preliminary study on the antibacterial activity of some medicinal plants of Khuzestan (Iran). Asian Pac J Trop Med. 2010;3(3):180-4.

10. Oszmianski J, Wolniak M, Wojdylo A, Wawer I. Comparative study of polyphenolic content and antiradical activity of cloudy and clear apple juices. J Sci Food Agric. 2007;87(4):573-9.

11. Alviano DS, Alviano CS. Plant extracts: Search for new alternatives to treat microbial diseases. Curr Pharm Biotechnol. 2009;10(1):106-21.

12. Hossain MA, Panthi S, Asadujjaman M, Khan SA, Ferdous F, Sadhu SK. Phytochemical and pharmacological assessment of the ethanol leaves extract of Heritiera fomes Buch. Ham.(Family-Sterculiaceae). J Porphyr Phthalocyanines. 2013;2:95-101.

13. Basak UC, Das AB, Das P. Chlorophylls, carotenoids, proteins and secondary metabolites in leaves of 14 species of mangrove. Bull Mar Sci. 1996;58(3):6549.

14. Dang HCT. Antioxidant sin Heritiera fomes, amedicinal plant from the Mangrove Forest of Bangladesh [M.S. thesis], School of Pharmacy, University of Oslo, Oslo, Norway. 2007.

15. Naskar K, Guha BDN. Mangrove swamps of the Sundarbans. Naya Prokash. 1987.

16. Mondal S, Paul SK, Uddin SJ, Nahar L, Auzi AA, Sarker SD. A comparative study on the in vitro antibacterial activity of the pneumatophores of Heritiera fomes and Xylocarpus moluccensis. Ars Pharm. 2008;49(1):51-6.

Article History: Submission Date : 03-10-2020; Revised Date : 22-10-2020; Acceptance Date : 19-11-2020.

Cite this article: Kalyani C, Tulasi CDSLN, Swathi MS, Geetha A, Narasu ML, Saida L. Screening of Antimicrobial and Antioxidant Activity of Acetone Extracts of Heritiera fomes Whole Plant against Pathogens. Int. J. Pharm. Investigation, 2020;10(4):564-8. 